\title{
Systemic retinoids for treatment of recalcitrant IgA pemphigus
}

\author{
Franziska Schauer ${ }^{1}$, Johannes Steffen Kern ${ }^{1,2}$ and Dimitra Kiritsi ${ }^{{ }^{*}}$ (D)
}

\begin{abstract}
IgA pemphigus is an exceedingly rare autoimmune blistering disorder, caused by IgA autoantibodies against desmosomal proteins. No treatment option has been found to be universally effective. The disease is often recalcitrant to oral steroids and immunosuppressants. Here, we describe the use of systemic retinoids for the treatment of recalcitrant IgA pemphigus in 3 cases. Although the use of acitretin has been reported before, we present for the first time the positive effects of alitretinoin in treatment of 2 patients with IgA pemphigus. Besides hyperlipoproteinaemia requiring use of hypolipidemic agents in one case, alitretinoin was well-tolerated and has generally a more favorable side effect spectrum than immunosuppressants.
\end{abstract}

Keywords: Autoimmune skin blistering, Alitretoin, Acitretin, Desmosomes, Desmocollin

\section{Introduction}

IgA pemphigus is an autoimmune blistering disorder, caused by IgA autoantibodies against keratinocyte cell surface antigens, desmocollins 1-3 and sometimes desmogleins 1 and 3. Based on clinical and histopathological characteristics it can be subdivided into subcorneal dermatosis type (SPD) and intraepidermal neutrophilic type (IEN) $[1,2]$ The patients present with flaccid pustules solely or on scaly erythematous plaques, often arranged in an annular or circinate pattern $[3,4]$, which are commonly itchy and located on the trunk. No treatment option has been found to be universally effective. The disease is often recalcitrant to local and/ or oral steroids and immunosuppressants [5]. Given the extreme rarity of the disease no controlled treatment trials exist or are likely to be conducted. We describe the novel use of alitretinoin in two out of three of our IgA pemphigus patients as a steroid-sparing agent.

\section{Patients and methods}

Over the last 10 years we cared for three female patients with IgA pemphigus, with disease presenting around the age of 60 (Fig. 1). The diagnostic analyses performed are summarized in Table 1 and Additional file 1: Figure S1.

\footnotetext{
*Correspondence: dimitra.kiritsi@uniklinik-freiburg.de

${ }^{1}$ Department of Dermatology, Medical Center- University of Freiburg, Faculty of Medicine, University of Freiburg, Hauptstr. 7, 79104 Freiburg, Germany Full list of author information is available at the end of the article
}

Two of them have an underlying monoclonal gammopathy of undetermined significance (MGUS). Bence Jones light chains are negative. In the other case an underlying haematological condition or other malignancy was excluded. Interestingly, all three patients had a recalcitrant disease with at least four immunosuppressive or immunomodulatory drugs given, resulting in unsatisfactory response and/ or accompanied by intolerable side effects (Table 1). Besides local steroids the following treatments were used: dapsone, azathioprine, mycophenolate mofetil, colchicine, prednisolone, methotrexate, anakinra, cyclosporine and cyclophosphamide. In all three patients we initiated treatment with acitretin at dosage of $10-30 \mathrm{mg}$, which has been reported before to be effective in a few cases [6].

\section{Results and discussion}

The treatment with the retinoid acitretin in all three patients resulted in a satisfactory, at least partial disease response. In two out of three cases, however, side effects (dizziness, hair loss and severe mucosal xerosis) occurred, prompting switch to the retinoid alitretinoin, which was given at a dosage of $30 \mathrm{mg}$ daily. Alitretinoin is a novel systemic, endogenous retinoid acting as a pan-agonist for the nuclear retinoid receptors retinoic acid receptor (RAR) and retinoid-X-receptor (RXR). It is the first systemic treatment to be approved in the EU for patients with severe chronic hand eczema unresponsive to potent topical corticosteroids.

(c) The Author(s). 2018 Open Access This article is distributed under the terms of the Creative Commons Attribution 4.0 International License (http://creativecommons.org/licenses/by/4.0/), which permits unrestricted use, distribution, and reproduction in any medium, provided you give appropriate credit to the original author(s) and the source, provide a link to the Creative Commons license, and indicate if changes were made. The Creative Commons Public Domain Dedication waiver (http://creativecommons.org/publicdomain/zero/1.0/) applies to the data made available in this article, unless otherwise stated. 

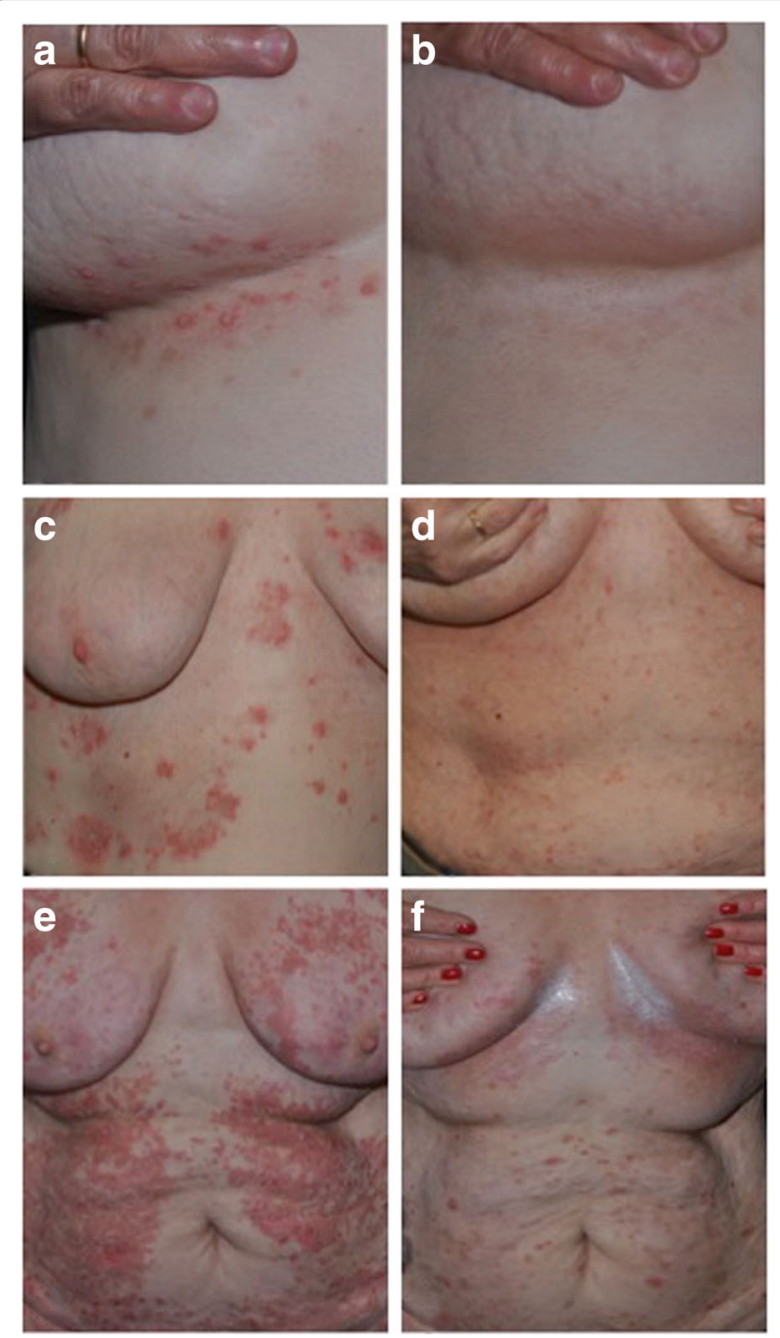

Fig. 1 All three patients are shown before and 2-3 months after treatment initiation with systemic retinoids. Patient 1 has flaccid vesicles within her submammary folds (a), with complete resolution around three months after initiation of alitretinoin (b). Patient 2 presented with confluent pustules on erythematous plaques (c), which improved significantly within three months after initiation of alitretinoin (d). The third patient had confluent erythematous papules and pustules on her trunk (e) with partial amelioration two months after initiation of acitretin at a dosage of $10 \mathrm{mg}$ per day ( $\mathbf{f}$ ) 


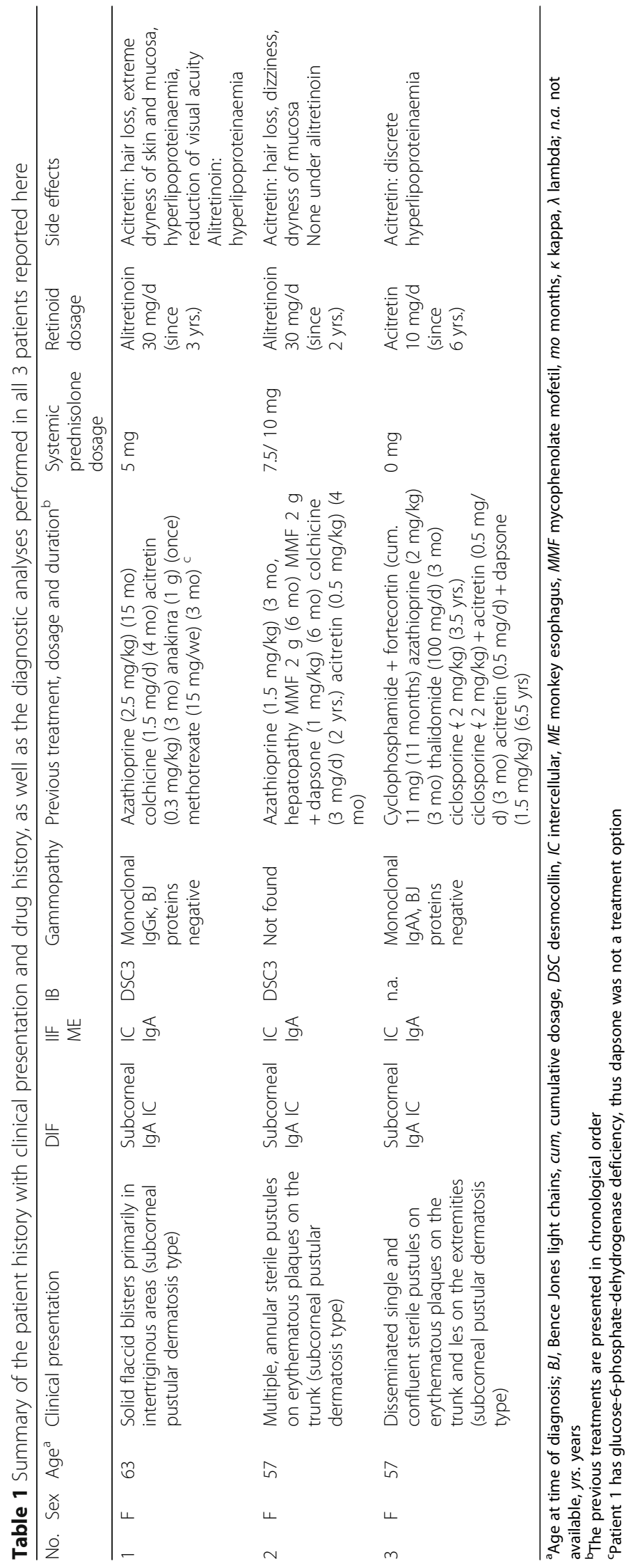


It has also been used in pilot studies for other chronic inflammatory skin disorders [7]. Besides hyperlipoproteinaemia requiring use of hypolipidemic agents in one of our patients - one of the most commonly reported side-effect of alitretinoin [8] - the drug was well-tolerated and has a favourable side effect spectrum compared to immunosuppressants. This is specifically important in light of the increased risk for malignancies, observed in patients with IgA pemphigus $[2,9]$.

Our observations suggest that due to their antiinflammatory and antiproliferative functions, systemic retinoids and especially alitretinoin represent an excellent treatment option for IgA pemphigus, an exceedingly rare autoimmune blistering skin disease, which is commonly recalcitrant to different treatment options [5].

\section{Additional file}

Additional file 1: Figure S1. Haematoxylin-eosin stainings of patients' biopsies, as well as direct immunofluorescence staining pictures with IgA for diagnostics are shown. Both the histological and the immunofluorescence findings are similar in the 3 cases. The histology shows spongiosis and intraepidermal blisters, as well as infiltrates of neutrophilic granulocytes (hematoxylin-eosin, original magnification $\times 100$ ). Direct immunofluorescence microscopy revealed IgA deposits at the upper part of the epidermis (original magnification $\times 200$ ). (TIF $548 \mathrm{~kb}$ )

\section{Abbreviations}

MGUS: monoclonal gammopathy of undetermined significance; RAR: retinoic acid receptor; RXR: retinoid-X-receptor

\section{Acknowledgements}

We thank the patients and their families, as well as other treating

dermatologists in the Department of Dermatology, Medical Center-University of Freiburg, Freiburg, Germany.

\section{Funding}

DK's work has been supported by the Mathilde-Wagner-Habilitationspreis from the University of Freiburg.

\section{Availability of data and materials}

Data sharing not applicable to this article as no datasets were generated or analysed during the current study.

\section{Authors' contributions}

DK and FS wrote the manuscript and prepared the figures; JSK read and improved the manuscript; all authors were involved in the design and conception of the study, as well as in the analysis and interpretation of the patient data. All authors read and approved the final manuscript.

\section{Ethics approval and consent to participate}

Not applicable (off-label treatment with systemic retinoids as part of compassionate use in an extremely rare disease).

\section{Consent for publication}

Has been obtained.

\section{Competing interests}

The authors declare that they have no competing interests.

\section{Publisher's Note}

Springer Nature remains neutral with regard to jurisdictional claims in published maps and institutional affiliations.

\section{Author details}

1 Department of Dermatology, Medical Center- University of Freiburg, Faculty of Medicine, University of Freiburg, Hauptstr. 7, 79104 Freiburg, Germany.

${ }^{2}$ Royal Melbourne Hospital, Parkville and Box Hill Hospital - Monash

University Eastern Health Clinical School, Box Hill, VIC, Australia.

Received: 28 February 2018 Accepted: 24 August 2018

Published online: 18 September 2018

\section{References}

1. Hashimoto T, Teye K, Ishii N. Clinical and immunological studies of 49 cases of various types of intercellular IgA dermatosis and 13 cases of classical subcorneal pustular dermatosis examined at Kurume University. $\mathrm{Br} J$ Dermatol. 2017; 176:168-75

2. Geller S, Gat A, Zeeli T, Hafner A, Eming R, Hertl M, et al. The expanding spectrum of IgA pemphigus: a case report and review of the literature. $\mathrm{Br} J$ Dermatol. 2014;171:650-6.

3. Kiritsi D, Hoch M, Kern JS. Annular flaccid pustules on the trunk. JAMA Dermatol. 2017:153:921-2.

4. Tsuruta D, Ishii N, Hamada T, Ohyama B, Fukuda S, Koga H, et al. IgA pemphigus. Clin Dermatol. 2011;29:437-42.

5. Moreno ACL, Santi CG, Gabbi TVB, Aoki V, Hashimoto T, Maruta CW. IgA pemphigus: case series with emphasis on therapeutic response. J Am Acad Dermatol. 2014;70:200-1.

6. Bellissen A, Lebas D, Wantz M, Gosset P, Lasek A, Modiano P. Efficacy of acitretin in IgA pemphigus. Ann Dermatol Venereol. 2013;140:793-6.

7. Blair HA, Scott LJ. Alitretinoin: a review in severe chronic hand eczema. Drugs. 2016;76:1271-9.

8. Diepgen TL, Pfarr E, Zimmermann T. Efficacy and tolerability of alitretinoin for chronic hand eczema under daily practice conditions: results of the TOCCATA open study comprising 680 patients. Acta Derm Venereol. 2012;92:251-5.

9. España A, Gimenez-Azcarate A, Ishii N, Idoate MA, Panizo C, Hashimoto T. Antidesmocollin 1 autoantibody negative subcorneal pustular dermatosistype IgA pemphigus associated with multiple myeloma. $\mathrm{Br} J$ Dermatol. 2015;172:296-8.
Ready to submit your research? Choose BMC and benefit from:
- fast, convenient online submission
- thorough peer review by experienced researchers in your field
- rapid publication on acceptance
- support for research data, including large and complex data types
- gold Open Access which fosters wider collaboration and increased citations
- maximum visibility for your research: over $100 \mathrm{M}$ website views per year
At BMC, research is always in progress.
Learn more biomedcentral.com/submissions 